\title{
Adding organic matter to restore wetland soils may increase methane generation and is not needed for hydric soil development
}

\author{
Brian $\operatorname{Scott}^{1}$, Andrew H. Baldwin ${ }^{1}$, Stephanie A. Yarwood ${ }^{1}$ \\ $5 \quad{ }^{1}$ Environmenal Science and Technology, University of Maryland, College Park, 20742, USA \\ Correspondence to: Brian Scott (bscott33@umd.edu)
}

\begin{abstract}
Methane $\left(\mathrm{CH}_{4}\right)$ emissions are a potent contributor to global warming and wetlands can be a significant $\mathrm{CH}_{4}$ source. In a microcosm study we evaluated how the practice of amending soils with organic matter as part of wetland restoration projects may affect $\mathrm{CH}_{4}$ production potential. Organic amendments including hay, manure, biosolids and compost were

10 evaluated at three different levels. Using 1-liter glass microcosms, we measured the production of biogenic gases over 60 days in two soils, a sandy loam (SL) and a sandy clay loam (SCL). Fresh organic amendments increased $\mathrm{CH}_{4}$ production, leading to potentially higher global warming potential and wetland $\mathrm{C}$ loss, particularly in sandy soils. Organic amendments increased biogenic gas production in two sequential steady state phases: Phase 1 produced some $\mathrm{CH}_{4}$ but was mostly carbon dioxide $\left(\mathrm{CO}_{2}\right)$ followed by Phase 2, two to six weeks later, with much higher total gas and nearly equal amounts of $\mathrm{CH}_{4}$ and

$15 \mathrm{CO}_{2}$. The $\mathrm{CH}_{4}$ from the SCL soil ranged from $0.003-0.8 \mathrm{cc} / \mathrm{Kg} /$ day in Phase 1 to $0.75-28$ in Phase 2 and the SL range from $0.03-16 \mathrm{cc} / \mathrm{Kg} /$ day in Phase 1 to $1.8-64$ in Phase 2 . We had set out to identify an organic amendment that would promote iron $(\mathrm{Fe})$ reduction without excess $\mathrm{CH}_{4}$, but amendments were not needed to produce $\mathrm{Fe}$ and make soils hydric. Adding fresh organic matter (hay) resulted in both excess $\mathrm{Fe}^{2+}$ and $\mathrm{CH}_{4}$ whereas composted amendments had little effect. The potential for excess methanogenesis should be taken into account when considering organic matter amendments in mitigation wetlands.
\end{abstract}

Keywords Methane emissions, mitigation wetlands, organic amendments

\section{Introduction}

The ecological benefits of wetlands are well documented, including their role as carbon sinks to stabilize global climate 25 (Mitsch, Bernal, and Hernandez 2015). Driven in part by this ecological contribution, from 1970 to 2015 new (human-made) wetlands have increased 233\% (Darrah et al. 2019). Between 2004 and 2009 the United States saw a net gain of 41,200 acres of freshwater wetlands: 891,600 acres of new wetlands to offset 850,400 acres of existing (carbon-sink) wetlands that were destroyed (Dahl 2010). Although human-made wetlands may effectively sequester carbon (C), it may take hundreds of years to offset their radiative forcing due to methane $\left(\mathrm{CH}_{4}\right)$ emissions (Neubauer 2014). With such a large number of new human30 made wetlands, and their potential to increase global warming, it is vital to consider factors that contribute to $\mathrm{CH}_{4} \mathrm{emissions}$ 
https://doi.org/10.5194/bg-2021-182

Preprint. Discussion started: 9 August 2021

(c) Author(s) 2021. CC BY 4.0 License.

\section{(c) (i)}

Some researchers have suggested that organic amendments such as straw, wood mulch, manure, and biosolids should be mixed into the soil to accelerate $\mathrm{C}$ storage by enhancing the conversion of plant-derived compounds to microbial residues (Richardson et al. 2016). Microbial residues, largely aliphatic-C from cell membrane lipids, can accumulate under anoxic conditions and are not directly accessible by methanogens (Chen et al. 2018). Belowground plant materials are preferentially

35 converted to soil organic matter (Mazzilli et al. 2015). Standing litter in natural wetlands is partially decomposed by fungi (Kuehn et al. 2011), and further decomposed by aerobic bacteria before entering the soil (Yarwood 2018). In saturated soils root residues of wetland plants contain suberin and cutin (Watanabe et al. 2013), which persist reducing biogenic gas production (Mikutta et al. 2006). Organic amendments are more representative of above-ground material, and studies suggest they are less amenable to soil $\mathrm{C}$ stabilization compared to natural plant inputs and may produce $\mathrm{CH}_{4}$ (Scott et al. 2020). Organic amendments may also contribute to $\mathrm{CH}_{4}$ generated from existing soil organic carbon (SOC) by priming existing SOC (Nottingham et al. 2009).

Iron $(\mathrm{Fe})$ oxides play a dual role in anoxic soils, being both an electron acceptor for organic $\mathrm{C}$ metabolism (Straub, Benz, and Schink 2001), and a stabilizing agent for SOC on mineral surfaces (Lehmann and Kleber 2015). As a metabolite, Fe reduction may compete with $\mathrm{CH}_{4}$ production (Huang, $\mathrm{Yu}$, and Gambrell 2009), couple it (Sivan, Shusta, and Valentine

45 2016), or enhancement it (Zhuang et al. 2015; Prakash, Chauhan, and Ferry 2019). In systems that are near pH neutral, Fe reduction does not have an energetic competitive advantage over $\mathrm{CH}_{4}$ production (Bethke et al. 2011). Organic matter interacts with metal-oxide mineral surfaces, which can affect both Fe reduction (Poggenburg et al. 2018) and C mineralization and storage (Amendola et al. 2018; Lalonde et al. 2012). Iron reduction is also one of the primary methods for determining if soils are hydric (National Technical Committee for Hydric Soils (NTCHS). 2015), a key indicator of wetland

50 success under mitigation guidelines.

We carried out a lab experiment using organic amendments commonly used in wetland restoration (biosolids (Bloom ${ }^{\circledR}$ - B, manure - M, composted yard waste (LeafGroß) - L, wood chips - W, and hay - H) and measured how they affected $\mathrm{CH}_{4}$ production and Fe-reduction. A series of 1-liter glass-jar microcosms were incubated with two different soils, a sandy clay loam (SCL), and a sandy loam (SL), both from recently created freshwater wetlands. The microcosms were kept under

55 anaerobic conditions to compare the ability of these substrates to support anaerobic metabolism. We hypothesized that organic amendments would stimulate dissimilatory Fe-reduction in soils (measured as soluble ferrous iron, $\mathrm{Fe}^{2+}$ ). Further, we hypothesized that amendments promoting Fe reduction would limit methanogenesis. We also tested differences between cured (i.e., aged) and uncured (fresh) organic amendments and hypothesized that uncured amendments would increase Fe reduction due to the presence of more labile, soluble, compounds. In the United States organic amendments are often

60 required in mitigation wetlands. However, there has not been a systematic evaluation of whether or not amendments promote hydric soil conditions (Fe reduction), or may lead to Fe toxicity (excess Fe reduction), or my cause excess $\mathrm{CH}_{4}$ production. 
https://doi.org/10.5194/bg-2021-182

Preprint. Discussion started: 9 August 2021

(c) Author(s) 2021. CC BY 4.0 License.

(c) (i)

\section{Materials and methods}

\subsection{Microcosm setup}

65 Saturated incubations were established using soil from two recent mitigation wetlands located in Maryland, USA. The first site $\left(76^{\circ} 50^{\prime} 40.35^{\prime \prime} \mathrm{W}, 38^{\circ} 47^{\prime} 5.41^{\prime \prime} \mathrm{N}\right)$ was most recently a horse pasture and will be referred to as SCL denoting the texture (sandy clay loam), a mesic anthrudult. The second site $\left(75^{\circ} 47^{\prime} 40.20^{\prime \prime} \mathrm{W}, 39^{\circ} 1^{\prime} 52.42^{\prime \prime} \mathrm{N}\right)$ was most recently a corn/soy farm with tile drains and was likely a wetland prior to conversion to farmland. The second site will be referred to as SL for the texture (sandy loam) and is classified as a mesic anthraquult (Supplemental Table S1). Both sites had been recently graded to establish wetland topography, so the upper portion of the soils were mixed endo- and umbr-aquic horizons. All soils were air-dried, sieved (2mm), and homogenized.

Microcosm experiments were conducted in 1000-mL glass straight-sided wide-mouth food canning jars. Each microcosm had a total of $600 \mathrm{cc}$ of solid material and was filled with water for a total volume of $660 \mathrm{cc}$. The volumes needed to be precise in order to facilitate headspace and liquid sampling and allow space for soil expansion. When amendments were added, an equal volume of soil needed to be removed so the total volume of solid material was a constant $600 \mathrm{cc}$. At the start of the experiment, the headspace was purged with nitrogen gas. The incubation temperature was $20^{\circ} \mathrm{C}$. Jar lids had precision drilled holes fitted with grey butyl rubber stoppers, making it possible to non-destructively remove the overlying liquid (for Fe and pH analyses) using a 3" needle. Since the head-space pressure increased due to biogenic gas production, atmospheric pressure was re-established during gas sampling events by piercing the septa with a 24-gauge needle connected to a $50 \mathrm{~mL}$

80 gas-tight syringe. This procedure allowed us to record the total volume of gas produced and collect gas samples $(0.01-1000$ $\mu \mathrm{L}$ ) under atmospheric pressure (Supplemental Figure S1). A small coating of silicone applied to stoppers after piercing prevented leaks. All microcosm trials were run with three replicates except where noted.

\subsection{Microcosm Experiments}

\subsubsection{Experiment 1}

85 We measured $\mathrm{CH}_{4}$ and $\mathrm{Fe}^{2+}$ production with various organic amendments, including composted yard waste (L), composted wood chips (W), class 1 biosolids (Bloom $\left.{ }^{\circledR}\right)$ - B, manure - M, and hay - H at three treatment levels: 8.8\% (v/v), 26\%, and $53 \%$, in two soils, a SL and a SCL. We used horse M for the SCL incubations and cow M for the SL incubations. This matched the wetland mitigation conditions at each field location. The treatment levels reflect the Maryland Department of Environment (MDE) recommendation for wetland restoration (60 cubic yards per acre assuming a 6 " mixing depth) $=1 \mathrm{x}, 3 \mathrm{x}$,

90 and 6x the MDE recommended level. All amendments were sieved to 5mm. Hay was chopped with a Wiley mill, blended, or cut with scissors until it could easily pass a $5 \mathrm{~mm}$ sieve. 
https://doi.org/10.5194/bg-2021-182

Preprint. Discussion started: 9 August 2021

(c) Author(s) 2021. CC BY 4.0 License.

(c) (i)

\subsubsection{Experiment 2}

We measured $\mathrm{CH}_{4}$ and $\mathrm{Fe}^{2+}$ production using cured (aged) and uncured (fresh) organic materials. We used two amendments, $\mathrm{B}$ and $\mathrm{M}$. The two cured materials were from the same two sources as the fresh material but were cured for a minimum of 3 months. We added the same amount of amendment to each microcosm based on organic matter (OM) content. Each amendment was evaluated for OM by loss-on-ignition (LOI) $\left(550^{\circ} \mathrm{C}\right.$ for $\left.2 \mathrm{~h}\right)$. Based on the percent OM we adjusted the amount of amendment so the final dose was $20 \mathrm{~g} \mathrm{OM} / 600 \mathrm{cc}$ soil. The microcosm setup was the same as Experiment 1 except we used the same volume of soil $(600 \mathrm{cc})$ in all microcosms. These microcosms were incubated for 13 days and sampled periodically for $\mathrm{Fe}^{2+}$ and biogenic gases.

\section{$100 \quad$ 2.2.3 Experiment 3}

We measured a) $\mathrm{CH}_{4}$ and b) $\mathrm{Fe}^{2+}$ production as a function of $\mathrm{pH}$. We used $\mathrm{H}$ leachate as a substrate as described in (McMahon et al. 2005). We leached $5.63 \mathrm{~g} \mathrm{H}$ with $125 \mathrm{cc}$ cold de-ionized water, shaking horizontally at $5^{\circ} \mathrm{C}$ for 24 hours. The leachate was filtered to $20 \mu \mathrm{m}$ and immediately placed into jars with $600 \mathrm{cc}$ SL soil and incubated for 22 days. The $\mathrm{pH}$ was adjusted to target levels of 5.6, 6.1, and 6.6 using a non-substrate buffer: 2-(N-morpholino) ethanesulfonic acid (MES).

105 To determine the necessary concentration of MES, we titrated SL (pH 5.8) to our maximum desired $\mathrm{pH}(6.6)$. We determined that the buffering capacity of the soils corresponded to $\sim 2 \mathrm{mN}$ in the $125 \mathrm{cc}$ of liquid (leachate volume), so we prepared microcosms using $125 \mathrm{cc}$ of $20 \mathrm{mN}$ MES buffer.

\subsubsection{Experiment 4}

We measured $\mathrm{Fe}^{2+}$ production using leached $\mathrm{H}$ as a substrate (as in Experiment 3) but compared these finding to those with unleached $\mathrm{H}$, and the $\mathrm{H}$ residuals.

\subsection{Soil, Liquid, and Gas Analyses}

Prior to the start of the experiments, we analyzed the SL and SCL for soil texture, percent soil C, and extractable iron. Soil texture was determined by hygrometer method: $50 \mathrm{~g}$ soil was added to a $1000 \mathrm{ml}$ cylinder with $0.5 \%$ hexametaphosphate. Sand settled after 1 minute and silt after 24 hours. Soil moisture content was determined as weight loss of approximately $5 \mathrm{~g}$

115 of soil dried at $105^{\circ} \mathrm{C}$ for 48 hours. We determined percent soil $\mathrm{C}$ using thermal combustion analysis at $950^{\circ} \mathrm{C}$ on a $\mathrm{LECO}$ CHN-2000 analyzer (LECO Corp., St. Joseph, MI). Iron extractions were performed sequentially with 1 M hydroxylamine hydrochloride in $25 \% \mathrm{v} / \mathrm{v}$ acetic acid; $50 \mathrm{~g} / 1$ sodium dithionite in solution $0.35 \mathrm{M}$ ace-tic acid / $0.2 \mathrm{M}$ sodium citrate buffered to $\mathrm{pH} 4.8 ; 0.2 \mathrm{M}$ ammonium oxalate / 0.17 M oxalic acid (pH 3.2) (Poulton and Canfield 2005).

Throughout the experiments we measured $\mathrm{Fe}^{2+}, \mathrm{pH}$, and biogenic gases in the headspace. In some cases, $\mathrm{Fe}^{2+}$ and $\mathrm{pH}$ were measured only at the end of the incubation. Using a 3" needle, we extracted $0.3-1 \mathrm{cc}\left(\right.$ for Fe${ }^{2+}$ ) and $1 \mathrm{cc}$ (for $\mathrm{pH}$ ) of the supernatant liquid to avoid disturbing soil in the jars. Liquid samples were removed during gas sampling, when atmospheric 
https://doi.org/10.5194/bg-2021-182

Preprint. Discussion started: 9 August 2021

(c) Author(s) 2021. CC BY 4.0 License.

\section{(c) (i)}

pressure was maintained, to avoid loss of biogenic gases and atmospheric contamination. Ferrous iron in supernatant liquid was measured with a HACH DR4000 spectrophotometer. The spectrophotometer was also used to measure Fe in the Feoxide extractions. Prior to analysis, extracted Fe-oxides were reduced by adding thioglycolic acid. To confirm the spectrophotometer accuracy, a subset of samples was also analyzed on a PerkinElmer PinAAcle 900T atomic absorption spectrometer. An Orion 9142BN electrode was used to determine $\mathrm{pH}$.

Gas samples were collected in $12 \mathrm{cc} \mathrm{N}$ purged exetainer vials and analyzed by injecting $5 \mathrm{cc}$ into a Varian Model 450-GC gas chromatograph. Since sample volume was typically $1 \mathrm{cc}$ or less, $5 \mathrm{cc}$ nitrogen gas was added to the vials immediately prior to analysis for $\mathrm{CO}_{2}$ and $\mathrm{CH}_{4}$. For fluorescent spectral scans dissolved organic matter was extracted from organic materials with 1:10 solid (weight) / deionized water (volume) for 24 hours and filtered to $0.45 \mu \mathrm{m}$ (Fischer et al. 2020). After diluting samples, emission spectra were recorded using an Aqualog fluorometer (Horiba Scientific; Edison, NJ).

\subsection{Data analysis}

Unless otherwise noted, statistical determinations were done using ANOVA in R or SAS. The $\mathrm{Fe}^{2+}$ concentrations were evaluated using contrasts for each of the amendments compared to the control using the multcomp package. The gas curves

135 were modelled as piecewise, bimodal linear functions using the R “Segmented” package (Muggeo 2008). Breakpoints were determined using the total gas curves but, in some cases, Segmented could not identify a breakpoint in the total gas curve, so $\mathrm{CH}_{4}$ curves were used as noted in Supplemental Figures S2 \& S3. Gas curves from H amendments did not fit a piecewise model and were modelled as sigmoidal functions using the SSgompertz function in R. However, Ssgompertz is sensitive to data scatter, particularly at the beginning and end of the curve, so in two cases, the total gas and $\mathrm{CO}_{2}$ curves for $\mathrm{H} 6 \mathrm{x}$ in the $\mathrm{SL}$, we fit the data with a power function in Excel.

\section{Results}

\subsection{Experiment 1a: Effect of organic amendments and soil type on $\mathrm{CH}_{4}$ gas production}

The addition of organic amendments increased $\mathrm{CH}_{4}$ production (Table 1). The amount of the increase depended on the soil type, when $\mathrm{CH}_{4}$ samples were collected, amendment, and dose. In general, the SL soil produced 2.4 times as much $\mathrm{CH}_{4}$ as

145 the SCL (Table 1 and Supplemental Figure S4a). Methane gas production occurred in two distinct steady-state gas production periods identified as Phase 1 and Phase 2. Therefore, we reported Phase $1 \& 2$ gas production rates, as well as the breakpoint (Table 1). A typical piecewise gas production curve is shown in Supplemental Figure S5 with individual gas curves shown in Supplemental Figures S2 (SCL) and S3 (SL). Supplemental Table S2 shows $\mathrm{CH}_{4}$ and includes total gas and carbon dioxide $\left(\mathrm{CO}_{2}\right)$. Some $\mathrm{CH}_{4}$ was produced almost immediately upon inundation (Phase 1), but after the breakpoint (40 days in both the SL and SCL soils), there is a large increase in $\mathrm{CH}_{4}$ as well as an average $4.7 \mathrm{x} \pm 1.9$ increase in total gas production (Supplemental Table S2). In the SCL soil, $\mathrm{CH}_{4}$ production in Phase 1 was $0.003 \mathrm{cc} / \mathrm{Kg} /$ day and with amendments increased to as much as $0.8 \mathrm{cc} / \mathrm{Kg}$ /day (Table 1). In Phase $2 \mathrm{CH}_{4}$ was $1.9 \mathrm{cc} / \mathrm{Kg} / \mathrm{day}$ and with amendments increased to as 
https://doi.org/10.5194/bg-2021-182

Preprint. Discussion started: 9 August 2021

(c) Author(s) 2021. CC BY 4.0 License.

\section{(c) (i)}

much as $28 \mathrm{cc} / \mathrm{Kg} /$ day (Table 1). In the SL soil, amendments increased $\mathrm{CH}_{4}$ from 0.04 to $16 \mathrm{cc} / \mathrm{Kg} /$ day in Phase 1 and from 1.8 to 64 in Phase 2.

155 Gas production rates increased with amendment dose. With the exception of $\mathrm{L}$ in the SL, all amendments reduced the breakpoint. Biosolids caused the largest shift, decreasing the breakpoint to as little as 5 days. While amendments generally increased $\mathrm{CH}_{4}$ there were exceptions. Low doses of cured amendments ( $\mathrm{L}$ and $\mathrm{W}$ ) had lower $\mathrm{CH}_{4}$ production rates than unamended soil: L1 in Phase 1 in both soils; L3 in the SL; L3 in the SCL (Phase 2 only); W1 in the SCL (Phase 2). Biosolids (B1) also lowered $\mathrm{CH}_{4}$ production rates in both soils (Phase 1) (Table 1).

160 Using fresh $\mathrm{H}$, biogenic gas production followed a sinusoidal pattern and we reported maximum $\mathrm{CH}_{4}$ production rate at the inflection point (Table 1). Hay was prone to floating and at higher doses was mostly present in the water column above the soil surface (not in contact with soil). In the in-stances where this occurred (H3 and H6 in the SCL), there was a decrease in overall gas production rate and very low $\mathrm{CH}_{4}$ - much lower than unamended soils (Table 1, Supplemental Table S2 and Supplemental Figures S2z \& S3z).

\subsection{Experiment 1b: Effect of organic amendments and soil type on $\mathrm{Fe}^{2+}$}

The type and dose of organic amendments affected total soluble $\mathrm{Fe}^{2+}$ production, compared to the unamended control, in only a limited number of cases (Figure 1, Supplemental Table S3). In the SL soil, L caused a decrease $(\mathrm{p}<0.05)$ in supernatant $\mathrm{Fe}^{2+}$ concentrations whereas $\mathrm{H}$ increased $\mathrm{Fe}^{2+}$ in both soils $(\mathrm{p}<0.05)$. Soil type affected the amount of soluble $\mathrm{Fe}^{2+}$ produced $(\mathrm{p}<0.05)$. We did not see a difference in $\mathrm{Fe}^{2+}$ in the unamended microcosms even though the SCL had 2.2x the amount of hydrochloramine hydrochloride extractable $\mathrm{Fe}$ (Fеннс) compared to the SL and had 7.6x more dithionite extractable Fe (Supplemental Table S1). Of the Feннсі in soil, 19\% or less in the SCL and 61\% or less in the SL was reduced to $\mathrm{Fe}^{2+}$. Hay was an exception, where up to $155 \%$ of the $\mathrm{Fe}_{\mathrm{HHCl}}$ in the SCL and $236 \%$ in the SL was reduced to $\mathrm{Fe}^{2+}$ (Supplemental Table S3). During the SL soil incubations, aqueous $\mathrm{Fe}^{2+}$ was measured simultaneous to $\mathrm{CH}_{4}$ production. In the $\mathrm{H}$ and $\mathrm{M}$ treatments, there was a marked increase in $\mathrm{CH}_{4}$ production when $\mathrm{Fe}^{2+}$ became asymptotic. However, with the other amendments, $\mathrm{Fe}^{2+}$ production continued or even increased during periods of high $\mathrm{CH}_{4}$ production (Supplemental Figure S6).

\subsection{Experiment 2a: Effect of cured versus fresh organic amendments on $\mathrm{CH}_{4}$ production}

In Experiment 1a, it appeared that curing may have had an effect on $\mathrm{CH}_{4}$ production. Fresh $\mathrm{H}$ produced the most $\mathrm{CH}_{4}$. The $\mathrm{H} 1$ trials had maximum $\mathrm{CH}_{4}$ production rates of 18.2 and $27.8 \mathrm{mg} / \mathrm{Kg}$ /day in the SCL and SL soils, respectively (Table 1).

180 The $\mathrm{H} 3$ and $\mathrm{H} 6$ doses would likely have been higher had some portion of the $\mathrm{H}$ not floated. The M6 trials produced the most $\mathrm{CH}_{4}$ at 27.7 and $64.0 \mathrm{mg} / \mathrm{Kg} /$ day in the SCL and SL soils, respectively. Of the amendments used, $\mathrm{M}$ was cured the least (after fresh $\mathrm{H}$, which was uncured). LeafGro, a commercial composted yard waste, was cured the most and produced very little $\mathrm{CH}_{4}$, in some cases less than the controls. Since we could not specify how long the organic material had been cured, we conducted a separate experiment with organic materials that had been cured at least 90 days, using B and M. Rather than use 
https://doi.org/10.5194/bg-2021-182

Preprint. Discussion started: 9 August 2021

(c) Author(s) 2021. CC BY 4.0 License.

(c) (i)

185 the same volumetric quantities, we used the same dose based on OM content. The results confirmed that curing has a strong influence on $\mathrm{CH}_{4}$ production. Methane production was much higher using fresh material in both cases and cured material resulted in a decrease in $\mathrm{CH}_{4}$ production (Table 2).

\subsection{Experiment 2b: Effect of cured versus fresh organic amendments on $\mathrm{Fe}^{2+}$ production}

In Experiment 1b, we observed that curing also had an effect on the amount of $\mathrm{Fe}^{2+}$ produced. Hay was the only amendment

190 that produced significantly more $\mathrm{Fe}^{2+}$ and the use of $\mathrm{L}$ saw a significant reduction in $\mathrm{Fe}^{2+}$ (Figure 1). In Experiment 2 we used biosolids (B) and manure (M) that had been cured at least 3 months. Whether the material had been cured had a strong influence on $\mathrm{Fe}^{2+}$ production and $\mathrm{Fe}^{2+}$ was higher using fresh material in both cases (Figure 2).

\subsubsection{Spectral analysis of cured and uncured organic matter}

We observed differences in $\mathrm{CH}_{4}$ and $\mathrm{Fe}$ reduction rates in cured versus uncured organic material. The fluorescent spectral 195 signatures of the cured materials (B and M) were similar as were the signatures of fresh material (Supplemental Figure S7). The fluorescent signatures varied due to curing, but not due to the source material. The difference in signatures was indicative of higher concentrations of organic (humic) acids and lower nominal oxidation state in the cured materials. We considered other organic matter characterization methods such as the material's carbon to nitrogen ratio, but we did not find another reliable predictor of $\mathrm{CH}_{4}$ and $\mathrm{Fe}^{2+}$ production other than curing.

\subsection{Experiment 3: Effect of $\mathrm{pH}$ on a) $\mathrm{CH}_{4}$ and b) $\mathrm{Fe}^{2+}$ production}

The soil $\mathrm{pH}$ affected both $\mathrm{CH}_{4}$ and $\mathrm{Fe}^{2+}$ production. In Experiment 1, we observed that on $\mathrm{Fe}^{2+}$ varied with $\mathrm{pH}$ in the SL soil $(p<0.001$; Supplemental Figure 8a), but there was little variation in the SCL ( $p=0.45$; Supplemental Figure $8 b$ ). In order to isolate the effect of $\mathrm{pH}$, we performed experiment 3 using a single substrate (H leachate) in the SL soil. Higher $\mathrm{pH}$ increased the $\mathrm{CH}_{4}$ production rate in both Phase 1 and 2 (Table 3) and reduced the production of $\mathrm{Fe}^{2+}$ (Figure 3).

\section{3.6 Experiment 4: Leached versus unleached $\mathrm{H}$ and $\mathrm{pH}$ considerations}

In Experiment 4 we measured $\mathrm{Fe}^{2+}$ produced from $\mathrm{H}, \mathrm{H}$ leachate, and the $\mathrm{H}$ residuals (Figure 4). The $\mathrm{H}$ residuals appeared to produce more $\mathrm{Fe}^{2+}$ than the leachate. However, as noted on the figure, leaching also resulted in a change in the system $\mathrm{pH}$. Using the results from Experiment 2, we predict that had the pHs been the same, there would have been no difference in $\mathrm{Fe}^{2+}$ production between H, H residuals, and leachate (Supplemental Figure S9). Therefore, we re-evaluated the results from

210 Experiment $2 \mathrm{~b}$, correcting for $\mathrm{pH}$ and confirmed that the organic material age accounts for differences in $\mathrm{Fe}^{2+}$ production (Supplemental Figure S10). Similarly, we considered whether $\mathrm{pH}$ affected the out-come of Experiment 1 results. However, a MANOVA analysis of the Experiment 1 data (Supplemental Table S4) indicated that $\mathrm{pH}$ had a small effect $(\mathrm{p}=0.30)$ compared to organic matter type and dose $(\mathrm{p}<0.0001)$. 
https://doi.org/10.5194/bg-2021-182

Preprint. Discussion started: 9 August 2021

(c) Author(s) 2021. CC BY 4.0 License.

\section{(c) (i)}

\section{Discussion}

$215 \mathrm{Net}_{\mathrm{CH}_{4}}$ emissions are a primary factor that determines whether a wetland is a $\mathrm{C}$ sink or contributes to long term global warming (Neubauer and Verhoeven 2019). Soil management practices, such as wetland restoration methods, can have a large impact on production of $\mathrm{CH}_{4}$ and total greenhouse gases (Paustian et al. 2016). Our data indicate that organic amendments used in mitigation wetlands can have a large influence on $\mathrm{CH}_{4}$ production. Cured organic amendments $(\mathrm{L}$ and W) only slightly increased $\mathrm{CH}_{4}$ emissions, whereas fresh material $(\mathrm{M}$ and $\mathrm{H})$ resulted in large increases (Table 1 and Supplemental Table S2). This is consistent with field studies where comparable cured amendments (composted wood and yard waste), did not result in increased $\mathrm{CH}_{4}$ emissions (Winton and Richardson 2015), but straw (Ballantine et al. 2015) and peat bales (Green et al. 2014) increased $\mathrm{CH}_{4}$. Curing produces humic acids and increases the nominal oxidation state (NOSC) of $\mathrm{C}$ (Guo, Liu, and Wu 2019). When cured material is then subjected to methanogenic conditions, less $\mathrm{CH}_{4}$ is produced to maintain an electron balance (Yao and Conrad 2000).

225 Following soil inundation, we observed two distinct gas production phases (Phase 1 and 2). This pattern is difficult to distinguish in unamended soils but has been reported previously (Yao and Conrad 1999). The breakpoint was similar: from 5 - 36 days in Yao and Conrad (1999) and 5 - 45 days in our study (Table 1). The Phase $2 \mathrm{CH}_{4}$ production rates in unamended soils were $0.96-3.98 \mathrm{mg} / \mathrm{Kg} /$ day in Yao and Conrad (1999) and $1.82-1.94$ in our study (Table 1). Organic amendments may contribute viable methanogens into the soil matrix. Biosolids, which may contain high populations of inactive methanogens, contributed to the early onset of Phase $2 \mathrm{CH}_{4}$ production (Table 1). Once established in soil, there is some evidence that methanogens can survive both desiccation and oxic conditions (Mayer and Conrad 1990; Ramakrishnan et al. 2001).

The increased gas production from organic amendments was more pronounced in SL compared to SCL, where there was 2.4x higher $\mathrm{CH}_{4}$ and 2.6x higher gas production (Supplemental Figures $4 \mathrm{a} \& 4 \mathrm{~b}$ ). There are few studies that compare $\mathrm{CH}_{4}$ production rates by soil type. (Yagi and Minami 1990) observed respiration rates that were 1.8x higher when using compost (approximate dose the same as our 1x treatment) in a SCL versus a loam soil. (Maietta et al. 2020) observed that respiration rates were higher in a sandy loam soil compared to a silty clay, with and without $3.3 \% \& 23 \%$ wetland hay. Our study showed that coarse grain soils are more vulnerable to SOC loss via $\mathrm{CH}_{4}$ production, which may be one reason why they are generally lower in SOC (Scott et al. 2020).

240 We considered the gas production from $\mathrm{H}$ microcosms separately because they followed a different pattern than the other amendments (Table 1), but the pattern was similar to other studies using hay (Glissmann and Conrad 2002) and wetland hay (Maietta et al. 2020). Our study adds to these findings by observing that $\mathrm{H}$ produced very low $\mathrm{CH}_{4}$ in the water column (after floating) compared to being mixed with soil. If this is generally true, applying organic matter as a mulch, rather than mixed into the soil, could greatly reduce $\mathrm{CH}_{4}$ emissions.

245 Reduction of Fe-oxides occurs in saturated soils in the presence of an organic substrate and is a key biogeochemical process in wetland soils. With sufficient time, hydric soils may develop redoximorphic features from Fe reduction; however, studies 
https://doi.org/10.5194/bg-2021-182

Preprint. Discussion started: 9 August 2021

(c) Author(s) 2021. CC BY 4.0 License.

\section{(c) $\underset{\mathrm{BY}}{\mathrm{BV}}$}

have not shown lasting redoximorphic development due to organic amendments (Gray 2010; Ott et al. 2020). Organizations responsible for constructing mitigation wetlands have an interest in documenting Fe reduction prior to redoximorphic feature development as evidence soils that are hydric. Some mitigation wetland practitioners experience challenges meeting hydric soil testing standards. Although reports in the scientific literature are rare, there are examples of sites meeting vegetation and hydrology wetland indicators, but not hydric soils (Berkowitz, Page, and Noble 2014). Both the soils we tested produced $\mathrm{Fe}^{2+}$ and would have passed hydric soils tests without the aid of an amendment.

We observed that fresh organic matter resulted in increased $\mathrm{Fe}^{2+}$ compared to cured organic matter (Figure 2), likely due to the presence of carbohydrates, allowing access to more crystalline Fe-oxides (Lentini, Wankel, and Hansel 2012). Fresh material such as hay has been promoted as a soil amendment in wetland construction (Melvin 2003). In some soils fresh organic matter amendments could access crystalline Fe making it more bioavailable. However, excess $\mathrm{Fe}^{2+}$ production could lead to Fe toxicity and ferrolysis (Kirk 2004), similar to the way fresh organic matter leads to SOC priming (Blagodatsky et al. 2010). Ferrolysis occurs when immobilized Fe-oxides are reduced to $\mathrm{Fe}^{2+}$ and are subject to hydraulic transport. We observed that cured amendments, like L, lowered $\mathrm{Fe}^{2+}$ concentrations (Figure 1), likely due to combination of factors including displacement of the Fe-bearing soil by the amendment and the presence of humic acids that are generated during curing (Guo, Liu, and Wu 2019). Humic acids often contain insufficient biogeochemical energy to drive dissimilatory Fe reduc-tion (Keiluweit et al. 2017), bind to $\mathrm{Fe}^{2+}$, removing it from the liquid phase (Catrouillet et al. 2014), and create insoluble precipitates (Shimizu et al. 2013).

Regulating $\mathrm{Fe}^{2+}$ production could influence the growth of wetland plants. For example, rice growth may be stimulated under low $\mathrm{Fe}^{2+}$ doses of $1 \mathrm{mg} / \mathrm{L}$ (Müller et al. 2015), but higher doses can produce detrimental Fe plaque (Pereira et al. 2014). Juncus effusus was stimulated at $25 \mathrm{mg} / \mathrm{L} \mathrm{Fe}^{2+}$ (Deng, Ye, and Wong 2009). North American native reed Phragmites australis ssp. americanus was stimulated at $11 \mathrm{mg} / \mathrm{L} \mathrm{Fe}^{2+}$ from ferrous sulfate (Willson et al. 2017), but the invasive Eurasian lineage of Phragmites australis seedling growth was inhibited by $\mathrm{Fe}^{2+}$ as low as $1 \mathrm{mg} / \mathrm{L}$ (Batty 2003). Soils high in free $\mathrm{Fe}^{2+}$ adversely affected P. australis growth by creating an Fe-oxide plaque on roots (Saaltink et al. 2017). Therefore, promoting Fe reduction could have a beneficial effect on native wetland plant growth while limiting invasive species seedling recruitment or growth. In our experiment, fresh organic amendments increase Fe production, but had the detrimental side effect of high $\mathrm{CH}_{4}$ generation.

Our results show that $\mathrm{pH}$ has a significant effect on both the production of $\mathrm{Fe}^{2+}$ (Figure 3) and $\mathrm{CH}_{4}$ (Table 3). Between $\mathrm{pH}$ 5.6 and 6.6, the lower $\mathrm{pH}$ produced more $\mathrm{Fe}^{2+}$ and less $\mathrm{CH}_{4}$, consistent with thermodynamic predictions (Ye et al. 2012). 275 Hydrogenotrophic methanogens can maximize $\mathrm{CH}_{4}$ production at $\mathrm{pH} 5$ (Bräuer, Yavitt, and Zinder 2004). In rice paddy soils, $\mathrm{CH}_{4}$ emissions had a clear peak at $\mathrm{pH}$ 7, but almost none below $\mathrm{pH} 5.5$ (Wang et al. 1993). The strong effect of $\mathrm{pH}$ underscores the need to take this parameter into account when interpreting data from experiments evaluating Fe-reduction and methanogenesis. Attempting to control the $\mathrm{pH}$ of soils could potentially introduce con-founding effects. We used an MES buffer with 10x the quantity we estimated from a soil titration and still saw shifts in the $\mathrm{pH}$ after incubation (data not shown). With a high residual soil acidity, the amount of buffer needed to control soil $\mathrm{pH}$ may increase the ionic strength to a 
https://doi.org/10.5194/bg-2021-182

Preprint. Discussion started: 9 August 2021

(c) Author(s) 2021. CC BY 4.0 License.

(c) (i)

level that could influence cellular sorption to mineral and Fe-oxide surfaces (Mills et al. 1994) as well as enzyme activity (Leprince and Quiquampoix 1996).

\section{Implications}

In our experiment, we saw that organic amendments significantly increased $\mathrm{CH}_{4}$ production, particularly after extended anaerobic periods. There is mounting concern that $\mathrm{CH}_{4}$ from mitigation and created wetlands may result in net global warming potential for decades to centuries (Neubauer 2014). Our results suggest that not only do organic amendments increase $\mathrm{CH}_{4}$ gas production overall, but uncured amendments can also decrease the time it takes before there is a large increase in both total gas production and $\mathrm{CH}_{4}$. Methane production is not constant and dramatically increases after several weeks; therefore, it may be possible to limit $\mathrm{CH}_{4}$ by designing systems with shorter flooding or saturation periods, alternating with drier conditions. Our lab study demonstrates the potential for significant $\mathrm{CH}_{4}$ emissions, but in a real system, methanotrophic activity could attenuate $\mathrm{CH}_{4}$ some of the emissions (Chowdhury and Dick 2013); however, this would not decrease the overall $\mathrm{C}$ loss from soils, it only changes the pathway. Our study suggests using organic amendments in nutrient- and carbon-poor coarse grained (sandy) soils could exacerbate SOC losses and greenhouse gas production. If organic amendments are to be used, cured amendments may be preferrable because they are not as prone to high $\mathrm{CH}_{4}$ generation and may attenuate $\mathrm{Fe}$ toxicity. Amendments that lower the soil $\mathrm{pH}$ would favor $\mathrm{Fe}$ reduction and limit methanogenesis (Marquart et al. 2019). When deciding whether or not the use of organic amendments for wetland mitigation is beneficial, or necessary, consideration should be given to whether or not the material has been cured, the material $\mathrm{pH}$, the soil type (coarse or fine grained), and expected hydroperiod.

\section{References}

Amendola D, Mutema M, Rosolen V, Chaplot V (2018) Soil hydromorphy and soil carbon: A global data analysis. Geoderma 324:9-17. https://doi.org/10.1016/j.geoderma.2018.03.005

Ballantine KA, Lehmann J, Schneider RL, Groffman PM (2015) Trade-offs between soil-based functions in wetlands restored with soil amendments of differing lability. Ecological Applications 25:215-225. https://doi.org/10.1890/13-1409.1

305 Batty LC (2003) Effects of External Iron Concentration upon Seedling Growth and Uptake of Fe and Phosphate by the Common Reed, Phragmites australis (Cav.) Trin ex. Steudel. Annals of Botany 92:801-806. https://doi.org/10.1093/aob/mcg205

Berkowitz JF, Page S, Noble CV (2014) Potential Disconnect between Observations of Hydrophytic Vegetation, Wetland Hydrology Indicators, and Hydric Soils in Unique Pitcher Plant Bog Habitats of the Southern Gulf Coast. Southeastern 
https://doi.org/10.5194/bg-2021-182

Preprint. Discussion started: 9 August 2021

(c) Author(s) 2021. CC BY 4.0 License.

\section{(c) (i)}

Bethke CM, Sanford RA, Kirk MF, et al (2011) The thermodynamic ladder in geomicrobiology. American Journal of Science 311:183-210. https://doi.org/10.2475/03.2011.01

Blagodatsky S, Blagodatskaya E, Yuyukina T, Kuzyakov Y (2010) Model of apparent and real priming effects: Linking microbial activity with soil organic matter decomposition. Soil Biology and Biochemistry 42:1275-1283. https://doi.org/10.1016/j.soilbio.2010.04.005

Bräuer SL, Yavitt JB, Zinder SH (2004) Methanogenesis in McLean Bog, an Acidic Peat Bog in Upstate New York: Stimulation by $\mathrm{H}_{2} / \mathrm{CO}_{2}$ in the Presence of Rifampicin, or by Low Concentrations of Acetate. Geomicrobiology Journal 21:433-443. https://doi.org/10.1080/01490450490505400

Catrouillet C, Davranche M, Dia A, et al (2014) Geochemical modeling of Fe(II) binding to humic and fulvic acids. Chemical Geology 372:109-118. https://doi.org/10.1016/j.chemgeo.2014.02.019

Chen X, Xu Y, Gao H, et al (2018) Biochemical stabilization of soil organic matter in straw-amended, anaerobic and aerobic soils. Science of The Total Environment 625:1065-1073. https://doi.org/10.1016/j.scitotenv.2017.12.293

Chowdhury TR, Dick RP (2013) Ecology of aerobic methanotrophs in controlling methane fluxes from wetlands. Applied Soil Ecology 65:8-22. https://doi.org/10.1016/j.apsoil.2012.12.014

325 Dahl TE (2010) Status and Trends of Wetlands in the Conterminous United States 2004 to 2009

Darrah SE, Shennan-Farpón Y, Loh J, et al (2019) Improvements to the Wetland Extent Trends (WET) index as a tool for monitoring natural and human-made wetlands. https://doi.org/10.1016/j.ecolind.2018.12.032

Deng H, Ye ZH, Wong MH (2009) Lead, zinc and iron $\left(\mathrm{Fe}^{2+}\right)$ tolerances in wetland plants and relation to root anatomy and spatial pattern of ROL. Environmental and Experimental Botany 65:353-362.

330 https://doi.org/10.1016/j.envexpbot.2008.10.005

Fischer S, McCarty G, Ramirez M, Torrents A (2020) Nitrogen release and leachable organic matter decomposition of anaerobically digested biosolids with variable pre-treatments. Waste Management 104:82-93. https://doi.org/10.1016/j.wasman.2019.12.049

Glissmann K, Conrad R (2002) Saccharolytic activity and its role as a limiting step in methane formation during the 335 anaerobic degradation of rice straw in rice paddy soil. Biology and Fertility of Soils 35:62-67. https://doi.org/10.1007/s00374-002-0442-z

Gray AL (2010) Redoximorphic Features Induced by Organic Amendments and Simulated Wetland Hydrology. Master's Thesis

Green SM, Baird AJ, Boardman CP, Gauci V (2014) A mesocosm study of the effect of restoration on methane $\left(\mathrm{CH}_{4}\right)$ 340 emissions from blanket peat. Wetlands Ecol Manage 22:523-537. https://doi.org/10.1007/s11273-014-9349-3

Guo X, Liu H, Wu S (2019) Humic substances developed during organic waste composting: Formation mechanisms, structural properties, and agronomic functions. Science of The Total Environment 662:501-510. https://doi.org/10.1016/j.scitotenv.2019.01.137 
https://doi.org/10.5194/bg-2021-182

Preprint. Discussion started: 9 August 2021

(c) Author(s) 2021. CC BY 4.0 License.

\section{(c) (i)}

Huang B, Yu K, Gambrell RP (2009) Effects of ferric iron reduction and regeneration on nitrous oxide and methane emissions in a rice soil. Chemosphere 74:481-486. https://doi.org/10.1016/j.chemosphere.2008.10.015

Keiluweit M, Wanzek T, Kleber M, et al (2017) Anaerobic microsites have an unaccounted role in soil carbon stabilization. Nat Commun 8:1771. https://doi.org/10.1038/s41467-017-01406-6

Kirk G (2004) The Biogeochemistry of Submerged Soils, 1st edn. Wiley

Kuehn KA, Ohsowski BM, Francoeur SN, Neely RK (2011) Contributions of fungi to carbon flow and nutrient cycling from

standing dead Typha angustifolia leaf litter in a temperate freshwater marsh. Limnol Oceanogr 56:529-539. https://doi.org/10.4319/10.2011.56.2.0529

Lalonde K, Mucci A, Ouellet A, Gélinas Y (2012) Preservation of organic matter in sediments promoted by iron. Nature 483:198-200. https://doi.org/10.1038/nature10855

Lehmann J, Kleber M (2015) The contentious nature of soil organic matter. Nature. https://doi.org/10.1038/nature16069

Lentini CJ, Wankel SD, Hansel CM (2012) Enriched iron (III)-reducing bacterial communities are shaped by carbon substrate and iron oxide mineralogy. Frontiers in microbiology 3:

Leprince F, Quiquampoix H (1996) Extracellular enzyme activity in soil: effect of pH and ionic strength on the interaction with montmorillonite of two acid phosphatases secreted by the ectomycorrhizal fungus Hebeloma cylindrosporum. European Journal of Soil Science 47:511-522. https://doi.org/10.1111/j.1365-2389.1996.tb01851.x

360 Maietta CE, Monsaint-Queeney V, Wood L, et al (2020) Plant litter amendments in restored wetland soils altered microbial communities more than clay additions. Soil Biology and Biochemistry 147:107846. https://doi.org/10.1016/j.soilbio.2020.107846

Marquart KA, Haller BR, Paper JM, et al (2019) Influence of pH on the balance between methanogenesis and iron reduction. Geobiology 17:185-198. https://doi.org/10.1111/gbi.12320

365 Mayer HP, Conrad R (1990) Factors influencing the population of methanogenic bacteria and the initiation of methane production upon flooding of paddy soil. FEMS Microbiology Letters 73:103-111. https://doi.org/10.1111/j.15746968.1990.tb03930.x

Mazzilli SR, Kemanian AR, Ernst OR, et al (2015) Greater humification of belowground than aboveground biomass carbon into particulate soil organic matter in no-till corn and soybean crops. Soil Biology and Biochemistry 85:22-30. https://doi.org/10.1016/j.soilbio.2015.02.014

McMahon SK, Williams MA, Bottomley PJ, Myrold DD (2005) Dynamics of Microbial Communities during Decomposition of Carbon-13 Labeled Ryegrass Fractions in Soil. Soil Science Society of America Journal 69:1238. https://doi.org/10.2136/sssaj2004.0289

Melvin NC (2003) Wetland Restoration, Enhancement, and Management. USDA Natural Resources Conservation Service. 375 https:/www.nrcs.usda.gov/wps/portal/nrcs/detail/national/water/wetlands/restore/?cid=nrcs143_010912

Mikutta R, Kleber M, Torn MS, Jahn R (2006) Stabilization of Soil Organic Matter: Association with Minerals or Chemical Recalcitrance? Biogeochemistry 77:25-56. https://doi.org/10.1007/s10533-005-0712-6 
https://doi.org/10.5194/bg-2021-182

Preprint. Discussion started: 9 August 2021

(c) Author(s) 2021. CC BY 4.0 License.

\section{(c) (i)}

Mills AL, Herman JS, Hornberger GM, DeJesús TH (1994) Effect of Solution Ionic Strength and Iron Coatings on Mineral Grains on the Sorption of Bacterial Cells to Quartz Sand. Applied and Environmental Microbiology 60:3300-3306. https://doi.org/10.1128/AEM.60.9.3300-3306.1994

Mitsch WJ, Bernal B, Hernandez ME (2015) Ecosystem services of wetlands. https://doi.org/10.1080/21513732.2015.1006250

Muggeo VMR (2008) segmented: An R Package to Fit Regression Models with Broken-Line Relationships. 8:7

Müller C, Kuki KN, Pinheiro DT, et al (2015) Differential physiological responses in rice upon exposure to excess distinct iron forms. Plant Soil 16

National Technical Committee for Hydric Soils (NTCHS). (2015) Hydric Soils Technical Note 11: Hydric Soils Technical Standard and Data Submission Requirements for Field Indicators of Hydric Soils.

Neubauer SC (2014) On the challenges of modeling the net radiative forcing of wetlands: reconsidering Mitsch et al. 2013. Landscape Ecol 29:571-577. https://doi.org/10.1007/s10980-014-9986-1

390 Neubauer SC, Verhoeven JTA (2019) Wetland Effects on Global Climate: Mechanisms, Impacts, and Management Recommendations. In: An S., Verhoeven J. (eds) Wetlands: Ecosystem Services, Restoration and Wise Use. Ecological Studies (Analysis and Synthesis). Springer, Cham, p 24

Nottingham AT, Griffiths H, Chamberlain PM, et al (2009) Soil priming by sugar and leaf-litter substrates: A link to microbial groups. Applied Soil Ecology 42:183-190. https://doi.org/10.1016/j.apsoil.2009.03.003

Ott ET, Galbraith JM, Daniels WL, Aust WM (2020) Effects of amendments and microtopography on created tidal freshwater wetland soil morphology and carbon. Soil Sci Soc Am j 84:638-652. https://doi.org/10.1002/saj2.20057

Paustian K, Lehmann J, Ogle S, et al (2016) Climate-smart soils. Nature 532:49-57. https://doi.org/10.1038/nature17174 Pereira EG, Oliva MA, Siqueira-Silva AI, et al (2014) Tropical Rice Cultivars from Lowland and Upland Cropping Systems Differ in Iron Plaque Formation. Journal of Plant Nutrition 37:1373-1394. https://doi.org/10.1080/01904167.2014.888744

400 Poggenburg C, Mikutta R, Schippers A, et al (2018) Impact of natural organic matter coatings on the microbial reduction of iron oxides. Geochimica et Cosmochimica Acta 224:223-248. https://doi.org/10.1016/j.gca.2018.01.004

Poulton SW, Canfield DE (2005) Development of a sequential extraction procedure for iron: implications for iron partitioning in continentally derived particulates. Chemical Geology 214:209-221. https://doi.org/10.1016/j.chemgeo.2004.09.003

405 Prakash D, Chauhan SS, Ferry JG (2019) Life on the thermodynamic edge: Respiratory growth of an acetotrophic methanogen. Sci Adv 5:eaaw9059. https://doi.org/10.1126/sciadv.aaw9059

Ramakrishnan B, Lueders T, Dun PF, Friedrich MW (2001) Archaeal community structures in rice soils from different geographical regions before and after initiation of methane production. FEMS Microbiology Ecology 37:12

Richardson CJ, Bruland GL, Hanchey MF, Sutton-Grier AE (2016) Soil Restoration: The Foundation of Successful Wetland

410 Reestablishment. In: Soil Restoration: The Foundation of Successful Wetland Reestablishment, 2nd edn. CRC Press, pp $469-493$ 
https://doi.org/10.5194/bg-2021-182

Preprint. Discussion started: 9 August 2021

(c) Author(s) 2021. CC BY 4.0 License.

\section{(c) (i)}

Saaltink RM, Dekker SC, Eppinga MB, et al (2017) Plant-specific effects of iron-toxicity in wetlands. Plant Soil 416:83-96. https://doi.org/10.1007/s11104-017-3190-4

Scott B, Baldwin AH, Ballantine K, et al (2020) The role of organic amendments in wetland restorations. Restor Ecol

415 28:776-784. https://doi.org/10.1111/rec.13179

Shimizu M, Zhou J, Schröder C, et al (2013) Dissimilatory Reduction and Transformation of Ferrihydrite-Humic Acid Coprecipitates. Environmental Science \& Technology 47:13375-13384. https://doi.org/10.1021/es402812j

Sivan O, Shusta SS, Valentine DL (2016) Methanogens rapidly transition from methane production to iron reduction. Geobiology 14:190-203. https://doi.org/10.1111/gbi.12172

420 Straub KL, Benz M, Schink B (2001) Iron metabolism in anoxic environments at near neutral pH. FEMS Microbiology Ecology 34:181-186. https://doi.org/10.1111/j.1574-6941.2001.tb00768.x

Wang ZP, DeLaune RD, Patrick WH, Masscheleyn PH (1993) Soil Redox and pH Effects on Methane Production in a

Flooded Rice Soil. Soil Science Society of America Journal 57:382. https://doi.org/10.2136/sssaj1993.03615995005700020016x

425 Watanabe K, Nishiuchi S, Kulichikhin K, Nakazono M (2013) Does suberin accumulation in plant roots contribute to waterlogging tolerance? Front Plant Sci 4:. https://doi.org/10.3389/fpls.2013.00178

Willson KG, Perantoni AN, Berry ZC, et al (2017) Influences of reduced iron and magnesium on growth and photosynthetic performance of Phragmites australis subsp. americanus (North American common reed). Aquatic Botany 137:30-38. https://doi.org/10.1016/j.aquabot.2016.11.005

430 Winton RS, Richardson CJ (2015) The Effects of Organic Matter Amendments on Greenhouse Gas Emissions from a Mitigation Wetland in Virginia's Coastal Plain. Wetlands 35:969-979. https://doi.org/10.1007/s13157-015-0674-y

Yagi K, Minami K (1990) Effect of organic matter application on methane emission from some Japanese paddy fields. Soil Science and Plant Nutrition 36:599-610. https://doi.org/10.1080/00380768.1990.10416797

Yao H, Conrad R (2000) Electron balance during steady-state production of $\mathrm{CH}_{4}$ and $\mathrm{CO}_{2}$ in anoxic rice soil. Eur J Soil

435 Science 51:369-378. https://doi.org/10.1046/j.1365-2389.2000.00330.x

Yao H, Conrad R (1999) Thermodynamics of methane production in different rice paddy soils from China, the Philippines and Italy. Soil Biology and Biochemistry 11

Yarwood SA (2018) The role of wetland microorganisms in plant-litter decomposition and soil organic matter formation: a critical review. FEMS Microbiology Ecology 94:. https://doi.org/10.1093/femsec/fiy175

440 Ye R, Jin Q, Bohannan B, et al (2012) pH controls over anaerobic carbon mineralization, the efficiency of methane production, and methanogenic pathways in peatlands across an ombrotrophic-minerotrophic gradient. Soil Biology and Biochemistry 54:36-47. https://doi.org/10.1016/j.soilbio.2012.05.015

Zhuang L, Xu J, Tang J, Zhou S (2015) Effect of ferrihydrite biomineralization on methanogenesis in an anaerobic incubation from paddy soil: Iron Mineralization and Methanogenesis. J Geophys Res Biogeosci 120:876-886. 
https://doi.org/10.5194/bg-2021-182

Preprint. Discussion started: 9 August 2021

(c) Author(s) 2021. CC BY 4.0 License.

\section{(c) (1)}

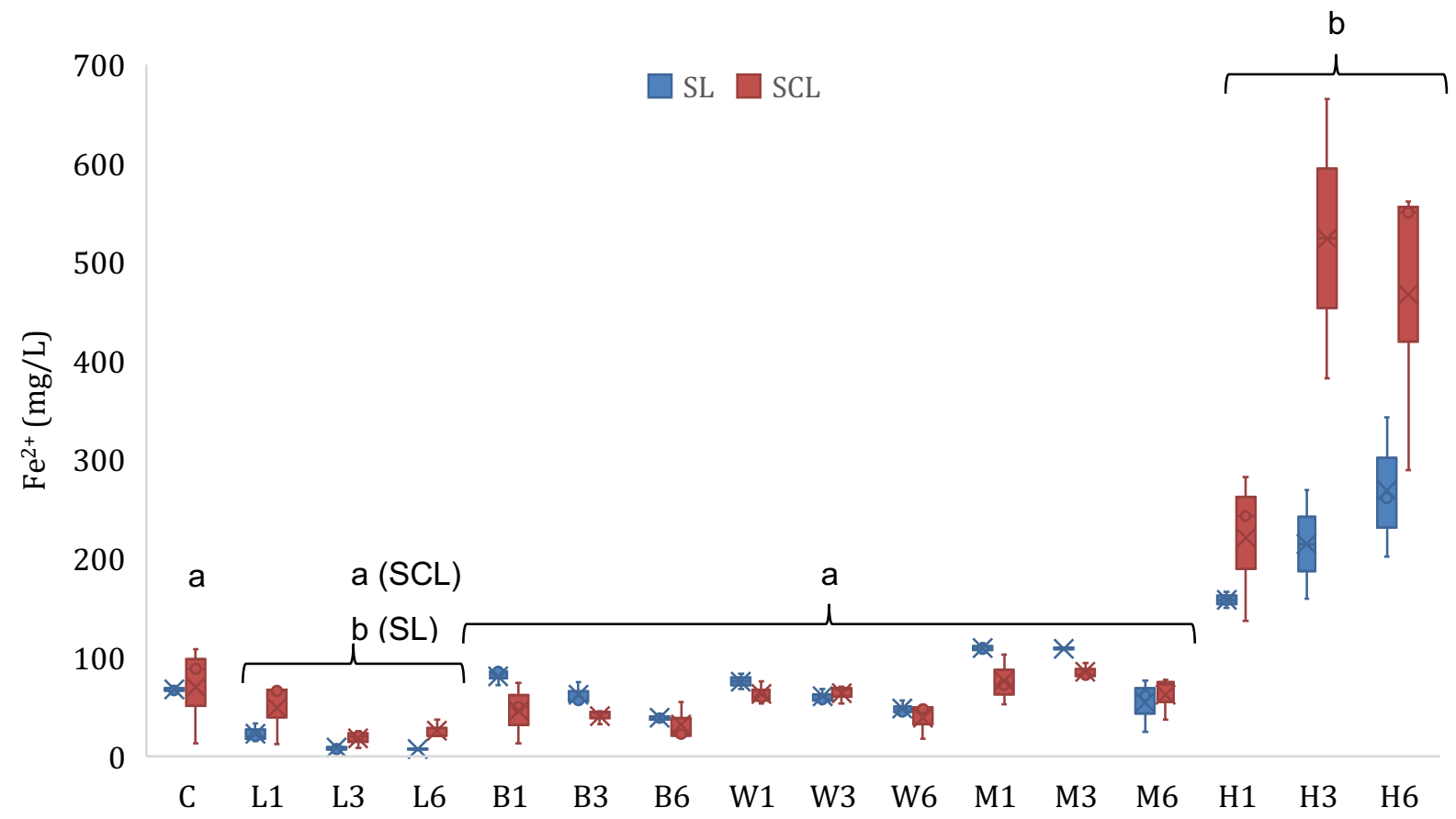

Fig. 1 (Experiment 1b) Ferrous iron $\left(\mathrm{Fe}^{2+}\right)$ concentration in the liquid phase at the end of the incubation period in microcosms receiving different organic amendment types and levels in Sandy Clay Loam (SCL) and Sandy Loam (SL) soils. C = no amendment control, $L=$ LeafGro ( ard waste), $B=$ biosolids, $W=$ wood chips, $M=$ manure, $H=$ hay. Numbers signify treatment level (1, 3, or 6 times amount of organic matter equivalent to $60 \mathrm{yd} 3$ acre-1 to a depth of 6 inches). Different lower-case letters signify differences $(p<0.05)$ based on contrasts compared to $C$ and brackets signify all results in the bracketed group were not statistically different. Hay increased total $\mathrm{Fe}^{2+}$ production compared to the $\mathrm{C}$ in both soils, and $\mathrm{L}$ decreased total $\mathrm{Fe}^{2+}$ production compared to C (SL only) 
https://doi.org/10.5194/bg-2021-182

Preprint. Discussion started: 9 August 2021

(c) Author(s) 2021. CC BY 4.0 License.

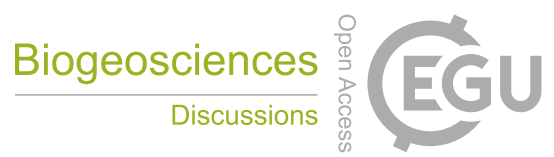

(c)

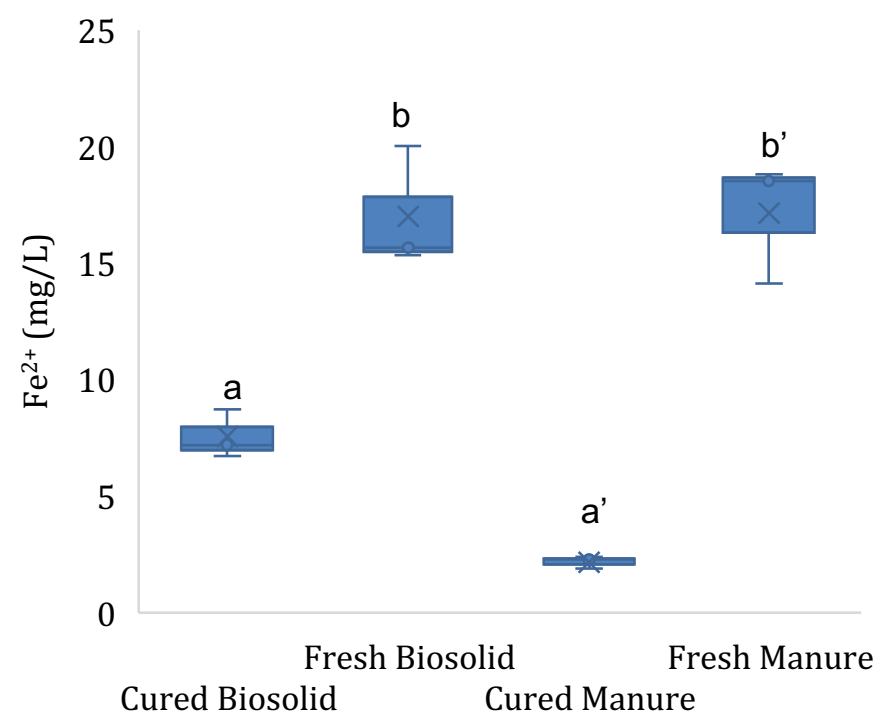

Fig. 2 (Experiment 2b) Ferrous iron $\left(\mathrm{Fe}^{2+}\right)$ concentration in the liquid phase at the end of the incubation period (13 days). 460 Incubation was carried out with cured and uncured biosolids (B) and manure (M) in SL soil. Letters indicate a difference at $\mathbf{p}<0.001$

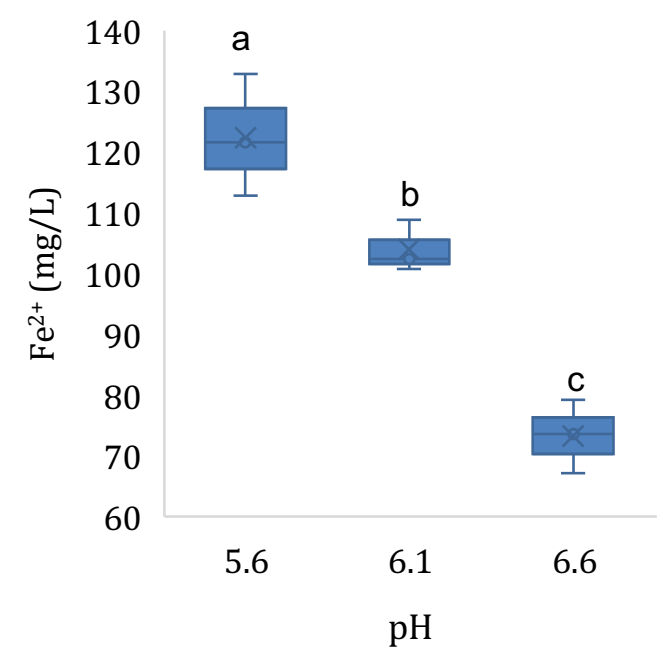

Fig. 3 (Experiment 3) Ferrous iron $\left(\mathrm{Fe}^{2+}\right)$ concentration in the liquid phase with varied in of microcosms receiving $\mathrm{H}$ in Sandy Loam soils. Letters indicate a difference at $\mathbf{p}<0.05$. 
https://doi.org/10.5194/bg-2021-182

Preprint. Discussion started: 9 August 2021

(C) Author(s) 2021. CC BY 4.0 License.

Table 1: (Experiment 1a). $\mathrm{CH}_{4}$ gas data for incubations of different organic amendment types and levels in silty clay loam (SCL) and sandy loam (SL) soils. Instances where organic amendments did not increase $\mathrm{CH}_{4}$ production are bolded.

\begin{tabular}{|c|c|c|c|c|c|c|c|c|}
\hline \multirow[b]{3}{*}{ Treatment } & \multicolumn{4}{|c|}{ Experiment 1 (SCL) } & \multicolumn{4}{|c|}{ Experiment 2 (SL) } \\
\hline & \multirow[b]{2}{*}{$\mathrm{r}^{2}$} & \multirow{2}{*}{$\begin{array}{c}\text { Phase } 1 \\
\mathrm{CH}_{4} \\
\text { (cc/Kg/day) }\end{array}$} & \multirow{2}{*}{$\begin{array}{l}\text { Breakpoint } \\
\text { (days) }\end{array}$} & \multirow{2}{*}{$\begin{array}{c}\text { Phase } 2 \\
\mathrm{CH}_{4} \\
\text { (cc/Kg/day) }\end{array}$} & \multirow[b]{2}{*}{$\mathrm{r}^{2}$} & \multirow{2}{*}{$\begin{array}{c}\text { Phase } 1 \\
\mathrm{CH}_{4} \\
\text { (cc/Kg/day) }\end{array}$} & \multirow{2}{*}{$\begin{array}{l}\text { Breakpoint } \\
\text { (days) }\end{array}$} & \multirow{2}{*}{$\begin{array}{c}\text { Phase } 2 \\
\mathrm{CH}_{4} \\
\text { (cc/Kg/day) }\end{array}$} \\
\hline & & & & & & & & \\
\hline Control & 0.959 & 0.003 & $40.0 \pm 4.5$ & 1.94 & 0.957 & 0.04 & $40.0 \pm 3.2$ & 1.82 \\
\hline B1 & 0.987 & 0.18 & $29.3 \pm 1.9$ & 3.45 & 0.880 & 0.04 & $8.6 \pm 3.0$ & 8.50 \\
\hline B3 & 0.974 & 0.80 & $20.1 \pm 3.4$ & 8.17 & 0.989 & 0.79 & $4.7 \pm 1.8$ & 15.28 \\
\hline B6 & 0.994 & 0.13 & $10.3 \pm 2.4$ & 23.29 & 0.992 & 1.27 & $9.1 \pm 1.2$ & 43.07 \\
\hline M1 & 0.997 & 0.04 & $40.2 \pm 2.1$ & 2.22 & 0.998 & 0.93 & $16.7 \pm 0.7$ & 21.02 \\
\hline M3 & 0.997 & 0.64 & $20.8 \pm 0.8$ & 10.89 & 0.992 & 5.85 & $17.2 \pm 1.5$ & 59.10 \\
\hline M6 & 0.956 & 0.30 & $22.1 \pm 3.2$ & 27.67 & 0.974 & 15.87 & $29.4 \pm 1.4$ & 64.00 \\
\hline L1 & 0.966 & 0.001 & $32.2 \pm 1.6$ & 0.090 & 0.993 & 0.03 & $38.3 \pm 1.2$ & 2.85 \\
\hline L3 & 0.983 & 0.01 & $32.0 \pm 2.2$ & 0.75 & 0.977 & 0.03 & $40.5 \pm 2.0$ & 3.50 \\
\hline L6 & 0.923 & 0.09 & $32.0 \pm 3.7$ & 2.24 & 0.988 & 0.26 & $44.8 \pm 1.3$ & 7.21 \\
\hline W1 & 0.986 & 0.01 & $34.0 \pm 2.9$ & 0.460 & 0.991 & 0.10 & $25.6 \pm 7.6$ & 2.19 \\
\hline W3 & 0.989 & 0.19 & $24.2 \pm 3.1$ & 3.52 & 0.974 & 0.36 & $23.2 \pm 2.3$ & 7.51 \\
\hline W6 & 0.981 & 0.24 & $13.0 \pm 2.4$ & 5.15 & 0.991 & 0.54 & $23.2 \pm 1.1$ & 18.60 \\
\hline H1 & N/A & N/A & N/A & 18.15 & N/A & N/A & N/A & 27.81 \\
\hline $\mathrm{H} 3$ & N/A & N/A & N/A & 0.04 & $\mathrm{~N} / \mathrm{A}$ & N/A & N/A & 25.52 \\
\hline H6 & N/A & N/A & N/A & 0.27 & N/A & N/A & N/A & 41.1 \\
\hline
\end{tabular}

Table 2: (Experiment 2a). Methane gas data for incubations with fresh and cured organic matter in SL (Experiment 1). Control data (*) from Experiment 1a (Table 1) included for reference. Letters indicate a difference at $\mathbf{p}<0.001$.

\begin{tabular}{|c|c|c|}
\hline & Phase 1 & Phase 2 \\
\hline Treatment & $\begin{array}{l}\text { Methane } \\
\text { (cc/Kg/day) }\end{array}$ & $\begin{array}{l}\text { Methane } \\
\text { (cc/Kg/day) }\end{array}$ \\
\hline Control*a & 0.04 & 1.8 \\
\hline Cured Biosolidsa & 0.003 & 0.37 \\
\hline Fresh Biosolids & 3.29 & 17.48 \\
\hline Cured Manure ${ }^{a}$ & 0.22 & 5.4 \\
\hline Fresh Manure $^{\mathrm{b}^{\prime}}$ & 3.85 & 42.36 \\
\hline
\end{tabular}


https://doi.org/10.5194/bg-2021-182

Preprint. Discussion started: 9 August 2021

(C) Author(s) 2021. CC BY 4.0 License.

(c) (1)

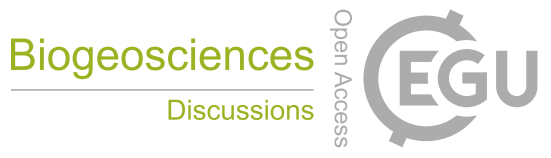

Table 3: (Experiment 3). Methane gas data versus pH of microcosms receiving $\mathrm{H}$ in Sandy Loam soils (Experiment 3). Letters indicate a difference at $\mathbf{p}<\mathbf{0 . 0 0 1}$.

480

\begin{tabular}{|c|c|c|}
\hline $\mathrm{pH}$ & $\begin{array}{c}\text { Phase } 1 \mathrm{CH}_{4} \\
(\mathrm{cc} / \mathrm{Kg} / \text { day })\end{array}$ & $\begin{array}{c}\text { Phase } 2 \mathrm{CH}_{4} \\
(\mathrm{cc} / \mathrm{Kg} / \text { day })\end{array}$ \\
\hline $5.6^{\mathrm{a}}$ & 0.44 & 10.6 \\
\hline $6.1^{\mathrm{b}}$ & 1.0 & 13.0 \\
\hline $6.6^{\mathrm{c}}$ & 1.8 & 13.8 \\
\hline
\end{tabular}

485

\section{Declarations}

\section{Funding}

Work was made possible by funding from the Maryland State Highway Administration (SHA/UM/4-53), the Maryland Water Resources Research Center (2017MD340B), and USDA National Institute of Food and Agriculture, Hatch Project 490 Number: MD-ENST-7741.

\section{Conflicts of interest/Competing interests}

Authors declare no conflict of interest

\section{Availability of data and material}

Significant data detail is available in the supplementary materials. Additional raw data available upon request.

\section{Code availability}

None 